\title{
Review
}

Neuro[mmunoModulation

Neuroimmunomodulation 2018;25:320-327

DOI: 10.1159/000495660
Received: June 14, 2018

Accepted after revision: November 16, 2018

Published online: January 10, 2019

\section{Zika Virus as a Possible Risk Factor for Autism Spectrum Disorder: Neuroimmunological Aspects}

\author{
Priscila Vianna ${ }^{a, b}$ Julia do Amaral Gomes ${ }^{a, b, d}$ Juliano André Boquett ${ }^{a, b}$

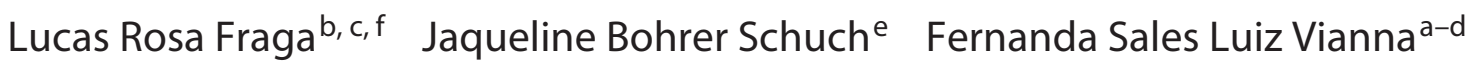 \\ Lavínia Schuler-Faccini ${ }^{a-c}$ \\ ${ }^{a}$ Department of Genetics, Institute of Biosciences, Universidade Federal do Rio Grande do Sul (UFRGS), Porto Alegre, \\ Brazil; b National Institute of Population Medical Genetics (INAGEMP), Porto Alegre, Brazil; ' Brazilian Teratogen \\ Information Service (SIAT), Medical Genetics Service, Hospital de Clínicas de Porto Alegre (HCPA), Porto Alegre, \\ Brazil; ${ }^{d}$ Genomic Medicine Laboratory, Hospital de Clínicas de Porto Alegre (HCPA), Porto Alegre, Brazil; ${ }^{e}$ Graduate \\ Program in Biomedical Gerontology, Pontifícia Universidade Católica do Rio Grande do Sul (PUCRS), Porto Alegre, \\ Brazil; fDepartment of Morphological Sciences, Institute of Health Sciences, Universidade Federal do Rio Grande do \\ Sul (UFRGS), Porto Alegre, Brazil
}

\section{Keywords}

Zika virus · Neuroimmunomodulation · Inflammation · Autism

\begin{abstract}
The recent outbreak of the Zika virus (ZIKV) and the discovery that perinatal Zika exposure can lead to the Congenital Zika Syndrome has promoted a call for prevention measures. Due to the increased number of babies born with microcephaly, structural brain abnormalities, and neurological alterations in regions affected by ZIKV, investigations were carried out in order to better understand this process. The maternal immune system directly influences the fetal central nervous system, and complications during pregnancy have been associated with neurodevelopmental disorders. Autism spectrum disorder (ASD), a neurodevelopmental disorder commonly manifested in the first years of life, is a disease with multifactorial etiology and is manifested typi-
\end{abstract}

cally by social and communication impairments, as well as stereotyped behaviors. Brain abnormalities, including both anatomically and functionally, can be observed in this disorder, suggesting delays in neuronal maturation and altered brain connectivity. It is known that some viral congenital infections, such as rubella, and cytomegalovirus can interfere with brain development, being associated with brain calcification, microcephaly, and ASD. Here, we reviewed a range of studies evaluating the aspects concerning brain development, immunological status during pregnancy, and neuroimmunomodulation in congenital viral infections, and we discuss if the fetal brain infection caused by ZIKV could predispose to ASD. Finally, we suggest a mechanism encompassing neurological and immunological pathways that could play a role in the development of ASD in infants after ZIKV infection in pregnancy.

(c) 2019 S. Karger AG, Basel

\section{KARGER}

(c) 2019 S. Karger AG, Basel 


\section{Congenital Zika Syndrome}

In early 2015, a Zika virus (ZIKV) outbreak was identified in the northeastern region of Brazil [1], followed by reports of an increased number of children born with severe microcephaly in Brazil in the same geographic area [2]. In 2016, after assessing several cases and reviewing criteria of teratogenesis, ZIKV was confirmed as a new teratogen in humans and responsible for the increase in the number of microcephaly cases in Brazil [3-5]. ZIKV teratogenesis affects mainly the central nervous system (CNS), presenting marked microcephaly with significant craniofacial disproportion, cortical malformations, and intracranial calcifications among other symptoms $[4,6$, 7]. Nonetheless, a proportion of babies born with a head circumference within the normal range ( $>33 \mathrm{~cm}$ for term boys and girls) may present cerebral and neurological abnormalities [8]. Several studies have focused on the identification of the mechanisms and pathways involved in ZIKV infection outcomes during pregnancy. In this work, we reviewed the embryologic and immunologic aspects during CNS development and ZIKV embryopathy. Finally, we suggest a mechanism encompassing neurological and immunological pathways that could play a role in the development of autism spectrum disorder (ASD) in infants after ZIKV infection in pregnancy.

\section{Normal Neurodevelopment}

The development of the CNS begins from the third week of gestation with the formation of the neural plate, which is a thickening of the embryonic ectoderm along the rostral-caudal midline. Differentiation of all embryonic stem cell lines involves complex cascades of molecular signaling. The interaction between expression of some genes and exposure to certain environmental factors contributes to this process [9].

The neural tube develops in the fourth week in the embryo's life. Initially, this structure contains only a single cell layer that surrounds a central canal. Neural progenitor cells are initially located adjacent to the central canal (i.e., future ventricular system) in the ventricular zone (VZ) [10]. Production of neurons involves the increase of the neural progenitor cell population [11]. In the developing brain, the division of this population of cells is asymmetric, leading to the formation of 2 different types of cells: neural progenitor cells and neurons. Progenitor cells stay in the proliferative zone, whilst neurons migrate radially from this area (most being produced in the VZ) to the center of the brain out to the developing neocortex [10].

As development proceeds, the brain becomes larger and the distance between the VZ and the most external layer increases. Hence, the mode of neuronal migration changes and the neurons use the radial glial guides to support their migration [12]. Radial glial guides extend a basal process that attaches to the pial surface of the brain, and the neurons use such processes as scaffolding to their migration [13]. The result of this orderly fashioned migration is that the neocortex has a structure of 6 well-defined layers. Initially, the brain is a smooth "lissencephalic" structure. Gradually, the increase in neuronal production and migration leads to an increase in its mass and area, and the brain develops the characteristic mature pattern of gyral and sulcal folding.

\section{ZIKV Infection during Pregnancy and Its Effects}

Infections during pregnancy can alter the embryo/fetal environment through maternal fever, dehydration, stress, nutritional impairment, and other related symptoms. It is known that a fraction of placental damage is caused by infections, and approximately half of all preterm births are associated with histological evidence of placental inflammation [14].

An increased number of babies born with microcephaly and neurological alterations in regions affected by ZIKV [15], as well as the emergence of the hypothesis involving a teratogenic effect of the virus infection [4], triggered several investigations in order to test the association between these 2 outcomes. Evidence linking ZIKV infection and brain abnormalities was observed through the detection of the virus in children exposed during pregnancy, including presence of viral RNA and antigens in the brain tissues and in placental tissues of early miscarriages $[16,17]$. Studies in mice infected with ZIKV found damage in the fetal CNS cells with maternal-fetal transmission through the placenta and tropism of the virus to cells in the cerebral cortex, including neural progenitor cells $[18,19]$.

It is known that cortical, ocular, and migratory disorders are some of the main characteristics observed, the occurrence of these and other malformations being dependent on the gestational period in which the mother was infected by ZIKV [7, 20]. There is a peculiar phenotype in affected babies, characterized by severe microcephaly with significant craniofacial disproportion, overlapping sutures, prominent occipital bone, destruction of 
the cerebral cortex, ventriculomegaly, cerebellar hypoplasia, intracranial calcifications, ophthalmic anomalies, and disorders of neuronal migration, such as lissencephaly and pachygyria. Severe neurological abnormalities and arthrogryposis are consequences of the prenatal cortical destruction $[6,7]$. These anomalies are the result of a sequence of events already described as the "Fetal Brain Disruption Sequence" [21], where the sudden destruction of the brain is followed by skull collapse. The term Congenital Zika Syndrome was coined [7, 22].

However, this phenotype is now considered only "the tip of the iceberg" and there is a spectrum of less severe abnormalities after congenital Zika infection. There is a significant number of children born with a head circumference within the normal range presenting a range of abnormalities, including postnatal microcephaly, brain calcifications, ophthalmic abnormalities, seizures, and other neurological dysfunctions. At the present moment, it is too early to assess cognitive abilities in these children $[6,23,24]$. Adams et al. [25], in a study in macaques, have demonstrated that even in the absence of microcephaly, the teratogenic action of ZIKV infection in the fetal brain is substantial and has long-lasting effects. These effects on the fetal brain include loss of fetal noncortical brain volume, injury to the ependymal epithelium, and loss of late fetal neuronal progenitor cells. Another study with macaques also described the long-lasting effects of ZIKV infection on behavior, brain structure and functions [26].

\section{Pregnancy and the Immune System}

Successful pregnancy depends on a constant balance between maternal and fetal modulators, playing roles in uterine quiescence, membrane integrity, and cervical competence [27]. The fetus is in intimate contact with the maternal immune system, being exposed to a range of substances ingested from the amniotic fluid, such as food antigens, microbes, and even maternal cell antigens [2831]. Since the fetus represents a semi-allogeneic graft to the maternal organism, it expresses paternal inherited antigens that make it a potential target for maternal immunity. The idea of maternal-fetal tolerance was first recognized and discussed by Medawar [32] in 1953. In this sense, regulatory and suppressive immunological mechanisms are usually put into action in an attempt to avoid rejection of the fetus. As an example of immune modulation during pregnancy, the maternal inflammatory cytokine profile Th1/Th2/Th17 is altered, allowing the correct fetal development and survival [33].
The initial phase of pregnancy (first trimester) is marked by an inflammatory immune profile favoring embryo implantation and angiogenesis [33, 34]. After this, the inflammatory maternal immune response should be continuously suppressed. For this, regulatory cytokines (e.g., IL-10) induce the expression of suppressive molecules in the trophoblast [35]. In addition, the Th17 and Treg cells regulate the immune system during pregnancy [36]. However, the process of immunomodulation during pregnancy may facilitate opportunistic infections that take advantage of this field.

The fetal immune system presents a strong innate immune response with antimicrobial properties able to inhibit bacterial colonization of the placenta [37]. Moreover, in the first trimester of pregnancy, the human fetus presents an immune response with the presence of CD4+ and CD8+ T cells produced by the fetal thymus $[38,39]$. An abundant and functional pool of FOXP3+ T-regulatory cells is also found in fetal lymphoid tissues [40]. Figure 1 represents a timeline of key events in the neurodevelopment of the fetus as well as the maternal immune system.

\section{Prenatal Adversities, Viral Infections, and ASD}

Immune adversities during pregnancy are often associated with fetal growth restriction and compensations in other organs in an attempt to protect the fetal brain development [41-43]. Complications during pregnancy can decrease the fetal blood supply, resulting in the shunt of blood from the peripheral organs to the CNS. The presence of maternal inflammation and infection was associated with alterations in brain development and behavior disorders in the fetus $[44,45]$. Proinflammatory cytokines damage oligodendrocytes during critical periods of brain development, which can result in perinatal inflammation and can contribute to the pathogenesis of brain lesions [46]. In relation to infections, it is known that some pathogens, such as STORCH (an acronym for syphilis, Toxoplasma gondii, rubella, cytomegalovirus, and herpes viruses), can alter brain development and are associated with alterations, such as brain calcifications, microcephaly, and neurodevelopmental disorders [47-49].

Altogether, evidence suggests that these complications during pregnancy are associated with neurodevelopmental disorders such as ASD [50]. ASD is commonly manifested in the first years of life and involves social and communication impairments, as well as stereotyped behaviors. Brain abnormalities, both anatomic and functional, 


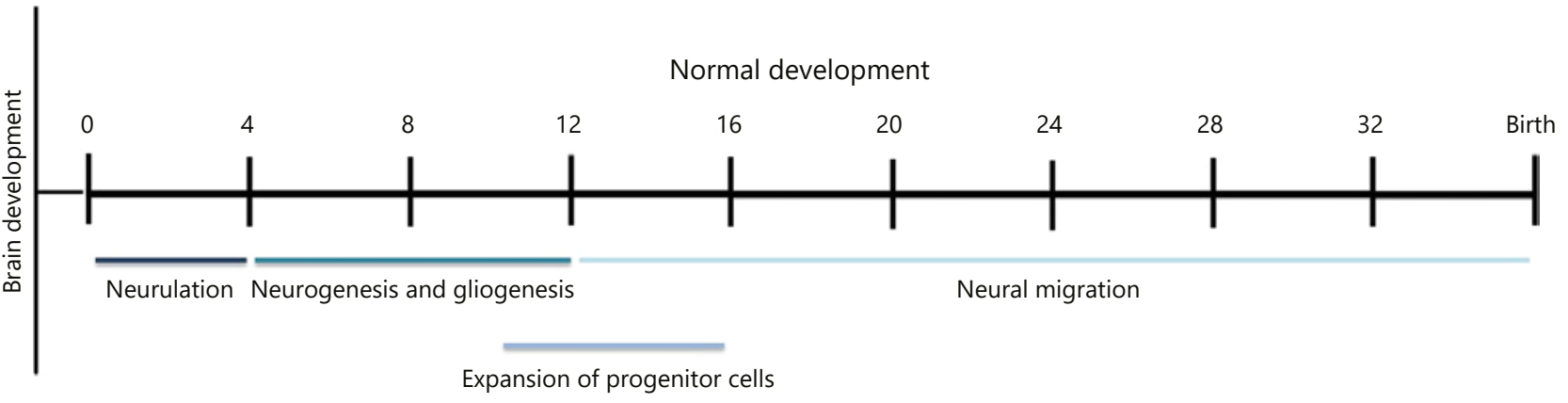

Myelination

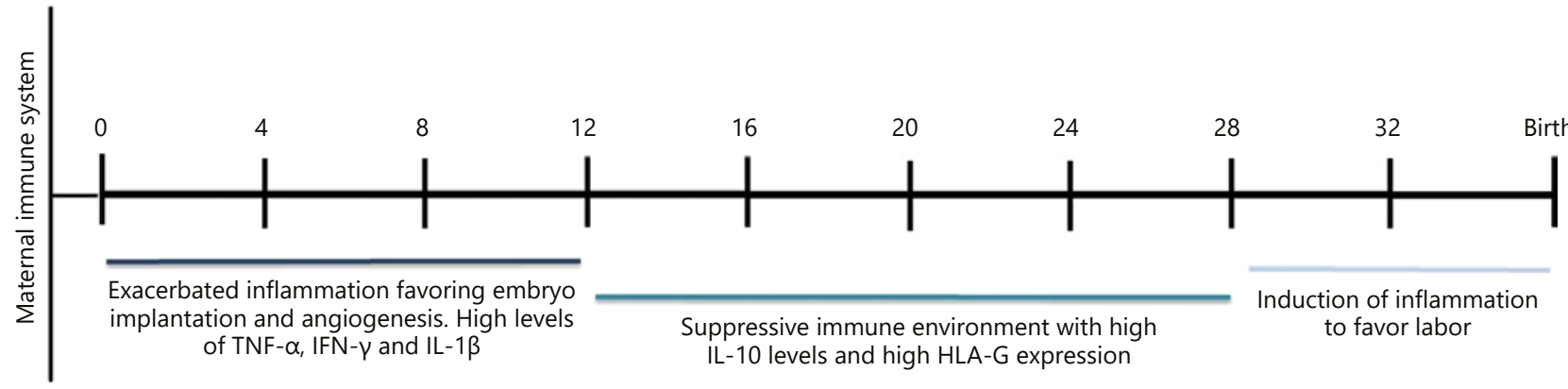

Fig. 1. Normal neurodevelopment. Each gestational week is marked by different events of neuromaturation and immunological responses in order to ensure the correct development of the brain of the fetus. The maternal immune system adopts proinflammatory and anti-inflammatory characteristics at the different trimesters of pregnancy that promote fetus survival and development.

are present in this disorder, suggesting delays in neuronal maturation and altered brain connectivity [51]. The mainly anatomical characteristics observed in ASD patients include dysplasias in the hippocampus, cerebellum, and neocortex; gray and white matter disorganization [52]; reduced volume of the corpus callosum regions and hippocampus [53], and abnormal patterns of cortical thickness [51, 54].

There is a range of genetic and environmental factors contributing to the susceptibility of the majority of ASD cases. Studies have indicated a tight relationship between the nervous and immune systems, acting as a neuro-immune network and influencing many mental disorders. The CNS can regulate the immune system through neuronal and hormonal pathways, and the immune system can influence the nervous system via cytokine production. In this sense, cytokines and chemokines can modulate brain function as well as influence the neurogenesis process, acting in response to infections, injuries, and inflammation.

ZIKV and Autism Spectrum Disorder

\section{Neuroinflammatory Responses and ASD}

During an initial immune response, the recognition of pathogenic antigens triggers inflammatory processes, releasing proinflammatory cytokines such as TNF- $\alpha$ and IL-6 [46]. For instance, TNF- $\alpha$ may regulate the dopaminergic differentiation as well as the apoptosis of neurons, leading to impaired fetal brain function [55]. Experimental studies demonstrated that CNS inflammation, due to cytokine production by the mother and/or child, may modify the activity of brain regions, such as the hippocampus [56].

Inflammatory response in the CNS mediated by microglial cells plays a role in neuronal damage and removes damaged cells by phagocytosis. In ASD, the number of activated microglial cells seems to be increased [57]. Alterations in synaptic and dendritic organization and neurotransmission were also observed [50]. Considering previous evidence linking autism to maternal infections and inflammatory profile, we suggest a robust association be-

Neuroimmunomodulation 2018;25:320-327 
Fig. 2. Model of neuroimmunomodulation of ZIKV infection and ASD: (a) during the initial immune response against ZIKV infection, an inflammatory response is triggered with the release of proinflammatory cytokines, such as IL-6 and TNF- $\alpha$; (b) the exacerbated inflammatory response against the virus may compromise viral elimination; (c) among the malformations observed in the affected babies (e.g., ocular), some have already been associated with an exacerbated inflammatory process; (d) we hypothesized whether the ZIKV infection process may generate long-term neuropathological effects in the infected mother's children, including the onset of neurodevelopmental disorders, such as ASD, since an exacerbated inflammatory process and the cytokines IL- 6 and TNF- $\alpha$ (released in response to ZIKV) have already been associated with ASD. ZIKV, Zika virus; ASD, autism spectrum disorder; IL-6, interleukin-6; TNF- $\alpha$, tumor necrosis factor alpha.

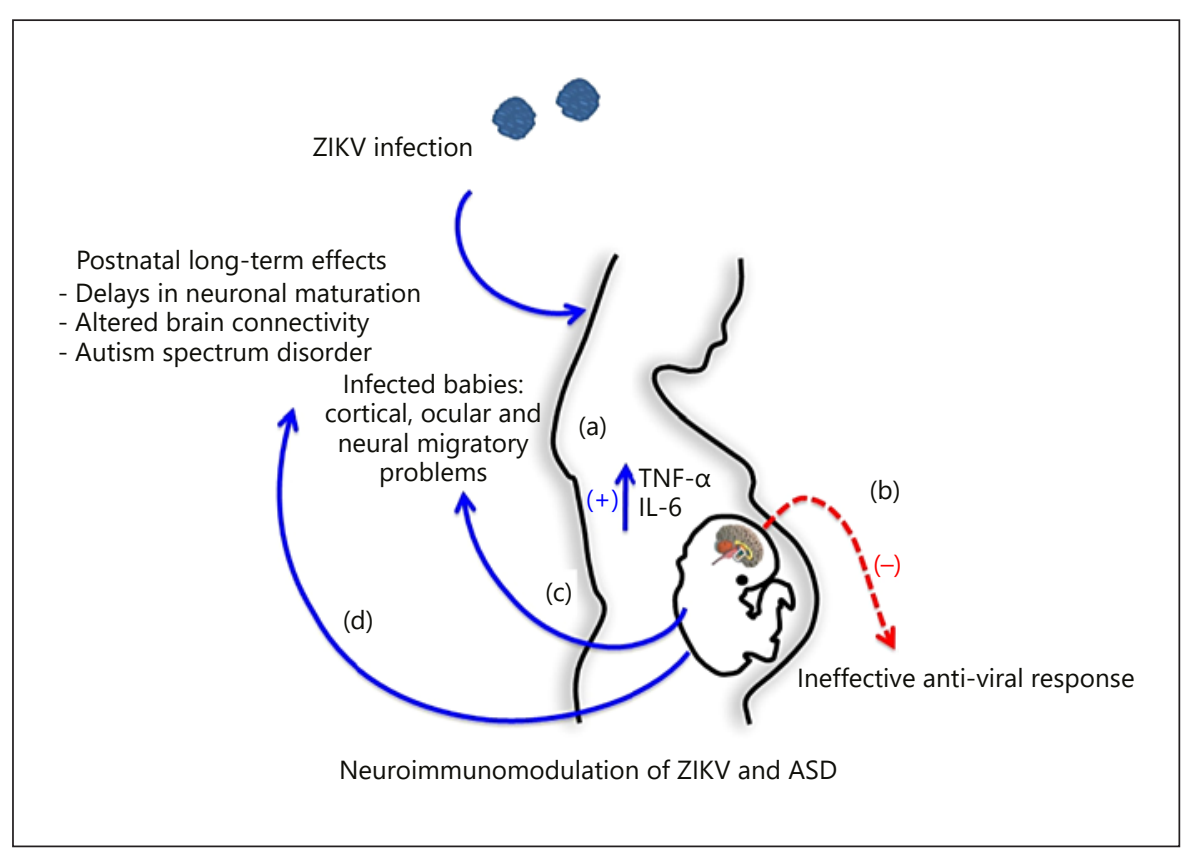

tween the immune system and ASD. In this sense, some studies have demonstrated increased cytokine levels in children with ASD [58-60]. IL-6 has been involved in several psychiatric disorders beyond autism. High levels of IL-6 were observed in the anterior cingulated gyrus, in the frontal cortices and cerebellum of ASD patients and could mediate autistic-like behaviors [61-63]. A mouse model of autism is associated with increased production of IL-6, and the inhibition of exacerbated IL- 6 production improves the sociability behavior in those mice [64]. Another mouse model of autism covers a situation of maternal infection and is marked by immune dysregulation and autistic-like symptoms in the offspring [65]. The administration of an anti-IL- 6 antibody prevents these behavioral changes [66].

Other cytokines are also associated with autism and/or autistic-like behaviors. Postmortem sampling of the brain also identified increased levels of TNF- $\alpha$ in patients with ASD [60]. Additionally, proinflammatory cytokines have been associated with deficits in the ASD core symptoms $[58,67]$. Previous studies observed alterations in the expression of toll-like receptors (TLRs), NF-kB, IL-27, IL17A, IL-10, and Foxp3 in BTBR mice - an experimental model for autism. These animals present repetitive behaviors and social deficits similar to those observed in children with ASD. After treatment with an adenosine A2A receptor agonist (a potential drug for immune, inflammatory, and neurodegenerative diseases), attenuated changes in behavior and expression of proinflammatory mediators were observed $[68,69]$. Also, another study reported lower levels of IL-2, IL-6, IL-9, interferon (IFN) $-\gamma$, and TNF- $\alpha$, as well as higher levels TGF- $\beta$, in BTBR mice following adenosine A2A receptor stimulation [70].

\section{Neuroimmunomodulation of ASD and ZIKV}

The inflammatory and immunological responses against ZIKV infection in pregnant women are of great interest since it is known that the presence of the virus in the CNS cells triggers the destruction of all adjacent tissue, causing cell death. It is not well understood how the immune system response to ZIKV infection is regulated. However, it is recognized that the inflammatory process triggered in an attempt to control the infection acts in both a beneficial and harmful way to the infective organism. Here, we discuss whether the inflammatory response to ZIKV infection and the brain damage caused by the virus in affected babies could favor the development of neurodevelopmental disorders such as ASD (Fig. 2). To support our theory, some points must be considered: (a) it is important to know the effects of the neuroimmunoregulation after virus infection; (b) we wonder whether the process of death of CNS cells infected by ZIKV and, consequently, tissue damage occurs due to the release of inflammatory mediators or (c) through direct lysis of the 
infected cells during the immune response against the virus. In this way, the tissue destruction would occur through the immune system's own cells lysing the infected target cells. It is well known that IL-6 is a key cytokine involved in autism [61]. Considering the facts above, little is known about the neuropathogenesis of ZIKV. ZIKV is able to reach the fetal neural cells when it crosses the fetal barrier through infection of cytotrophoblasts or transmigration of infected primary human placental macrophages. After virus infection, the human placental macrophages try to eliminate the virus by secreting type I IFNs; however, the cells remain permissive to viral replication.

Hamel et al. [71] have identified the TLR3 as the initial immune receptor involved in the sensing of ZIKV infection in human fibroblasts leading to type I and type II IFN responses. Olagnier et al. [72] have suggested that the viral infection of fetal neural progenitor cells could activate TLR3 immune responses, leading to a deregulation of genes that control apoptosis, resulting in severe damage to the embryonic brain. All of these inflammatory issues are relevant when it comes to a viral infection since the immune system may respond differently. Moreover, in the case of ZIKV, previous infections with other flaviviruses, such as dengue virus and yellow fever, may trigger a secondary immune response of differential magnitude given the great molecular similarity of some immunogenic epitopes among these correlated viruses.

The understanding of normal neurodevelopment and its comparison with neuropathogenesis during ZIKV infection are extremely relevant issues, not only for the identification of virus target cells but also for the identification of which structural, cognitive, motor, and behavioral damages are expected. It is known that ZIKV infection can occur at any time during pregnancy, and therefore at any point in development, causing harm to the baby to a greater or lesser extent. It is important to evaluate the long-term effects of ZIKV infection and its correlation with neurodevelopmental disorders, such as ASD.

\section{Disclosure Statement}

The authors declare no conflicts of interest.

\section{Funding Sources}

This work was supported by National Institute of Population Medical Genetics (INAGEMP) grants CNPq 573993/2008-4; CNPq/CAPES/MS (No. 14/2016 - Preventing and Combating the Zika Virus) and Coordenação de Aperfeiçoamento Pessoal de Nível Superior (CAPES, Finance Code 001).

\section{References}

1 Campos GS, Bandeira AC, Sardi SI. Zika Virus Outbreak, Bahia, Brazil. Emerg Infect Dis. 2015 Oct;21(10):1885-6.

2 Oliveira Melo AS, Malinger G, Ximenes R, Szejnfeld PO, Alves Sampaio S, Bispo de Filippis AM. Zika virus intrauterine infection causes fetal brain abnormality and microcephaly: tip of the iceberg? Ultrasound Obstet Gynecol. 2016 Jan;47(1):6-7.

3 Rasmussen SA, Jamieson DJ, Honein MA, Petersen LR. Zika Virus and Birth Defects-Reviewing the Evidence for Causality. N Engl J Med. 2016 May;374(20):1981-7.

4 Schuler-Faccini L, Ribeiro EM, Feitosa IM, Horovitz DD, Cavalcanti DP, Pessoa A, et al.; Brazilian Medical Genetics Society-Zika Embryopathy Task Force. Possible Association between Zika Virus Infection and Microcephaly - Brazil, 2015. MMWR Morb Mortal Wkly Rep. 2016 Jan;65(3):59-62.

5 Schuler-Faccini L, Sanseverino M, Vianna F, da Silva AA, Larrandaburu M, MarcolongoPereira C, et al. Zika virus: A new human teratogen? Implications for women of reproductive age. Clin Pharmacol Ther. 2016 Jul; 100(1):28-30.
6 van der Linden V, Pessoa A, Dobyns W, Barkovich AJ, Júnior HV, Filho EL, et al. Description of 13 Infants Born during October 2015-January 2016 with Congenital Zika Virus Infection without Microcephaly at Birth - Brazil. MMWR Morb Mortal Wkly Rep. 2016 Dec;65(47):1343-8.

7 Del Campo M, Feitosa IM, Ribeiro EM, Horovitz DD, Pessoa AL, França GV, et al.; Zika Embryopathy Task Force-Brazilian Society of Medical Genetics ZETF-SBGM. The phenotypic spectrum of congenital Zika syndrome. Am J Med Genet A. 2017 Apr;173(4): 841-57.

8 França GV, Schuler-Faccini L, Oliveira WK, Henriques CM, Carmo EH, Pedi VD, et al. Congenital Zika virus syndrome in Brazil: a case series of the first 1501 livebirths with complete investigation. Lancet. 2016 Aug; 388(10047):891-7.

9 Stiles J. The fundamentals of brain development: Integrating nature and nurture. Cambridge (MA): Harvard University Press; 2008.

10 Stiles J, Jernigan TL. The basics of brain development. Neuropsychol Rev. 2010 Dec;20(4): $327-48$.
11 Wodarz A, Huttner WB. Asymmetric cell division during neurogenesis in Drosophila and vertebrates. Mech Dev. 2003 Nov;120(11): 1297-309.

12 Rakic P. Mode of cell migration to the superficial layers of fetal monkey neocortex. Comp Neurol. 1972 May;145(1):61-83.

13 Nadarajah B, Parnavelas JG. Modes of neuronal migration in the developing cerebral cortex. Nat Rev Neurosci. 2002 Jun;3(6):423-32.

14 Chatterjee A, Chartrand SA, Harrison CJ, Felty-Duckworth A, Bewtra C. Severe intrauterine herpes simplex disease with placentitis in a newborn of a mother with recurrent genital infection at delivery. J Perinatol. 2001 Dec; 21(8):559-64.

15 Kleber de Oliveira W, Cortez-Escalante J, De Oliveira WT, do Carmo GM, Henriques CM, Coelho GE, et al. Increase in Reported Prevalence of Microcephaly in Infants Born to Women Living in Areas with Confirmed Zika Virus Transmission During the First Trimester of Pregnancy - Brazil, 2015. MMWR Morb Mortal Wkly Rep. 2016 Mar;65(9):242-7. 
16 Martines RB, Bhatnagar J, de Oliveira Ramos AM, Davi HP, Iglezias SD, Kanamura CT, et al. Pathology of congenital Zika syndrome in Brazil: a case series. Lancet. 2016 Aug; 388(10047):898-904.

17 Mlakar J, Korva M, Tul N, Popović M, Poljšak-Prijatelj M, Mraz J, et al. Zika Virus Associated with Microcephaly. N Engl J Med. 2016 Mar;374(10):951-8.

18 Cugola FR, Fernandes IR, Russo FB, Freitas BC, Dias JL, Guimarães KP, et al. The Brazilian Zika virus strain causes birth defects in experimental models. Nature. 2016 Jun; 534(7606):267-71.

19 Miner JJ, Cao B, Govero J, Smith AM, Fernandez E, Cabrera OH, et al. Zika Virus Infection during Pregnancy in Mice Causes Placental Damage and Fetal Demise. Cell. 2016 May; 165(5):1081-91.

20 Brasil P, Pereira JP Jr, Moreira ME, Ribeiro Nogueira RM, Damasceno L, Wakimoto M, et al. Zika Virus Infection in Pregnant Women in Rio de Janeiro. N Engl J Med. 2016 Dec; 375(24):2321-34.

21 Russell LJ, Weaver DD, Bull MJ, Weinbaum $\mathrm{M}$, Opitz JM. In utero brain destruction resulting in collapse of the fetal skull, microcephaly, scalp rugae, and neurologic impairment: the fetal brain disruption sequence. Am J Med Genet. 1984 Feb;17(2):509-21.

22 Moore CA, Staples JE, Dobyns WB, Pessoa A, Ventura CV, Fonseca EB, et al. Characterizing the Pattern of Anomalies in Congenital Zika Syndrome for Pediatric Clinicians. JAMA Pediatr. 2017 Mar;171(3):288-95.

23 Zin AA, Tsui I, Rossetto J, Vasconcelos Z, Adachi K, Valderramos S, et al. Screening Criteria for Ophthalmic Manifestations of Congenital Zika Virus Infection. JAMA Pediatr. 2017 Sep;171(9):847-54.

24 Nem de Oliveira Souza I, Frost PS, França JV, Nascimento-Viana JB, Neris RL, Freitas L, et al. Acute and chronic neurological consequences of early-life Zika virus infection in mice. Sci Transl Med. 2018 Jun; 10(444):eaar2749.

25 Adams Waldorf KM, Nelson BR, StencelBaerenwald JE, Studholme C, Kapur RP, Armistead B, et al. Congenital Zika virus infection as a silent pathology with loss of neurogenic output in the fetal brain. Nat Med. 2018 Mar;24(3):368-74.

26 Mavigner M, Raper J, Kovacs-Balint Z, Gumber S, O’Neal JT, Bhaumik SK, et al. Postnatal Zika virus infection is associated with persistent abnormalities in brain structure, function, and behavior in infant macaques. Sci Transl Med. 2018 Apr;10(435):eaao6975.

27 Challis JR, Lockwood CJ, Myatt L, Norman JE, Strauss JF 3rd, Petraglia F. Inflammation and pregnancy. Reprod Sci. 2009 Feb;16(2): 206-15.

28 Aagaard K, Ma J, Antony KM, Ganu R, Petrosino J, Versalovic J. The placenta harbors a unique microbiome. Sci Transl Med. 2014 May;6(237):237ra65.
29 Campbell DE, Boyle RJ, Thornton CA, Prescott SL. Mechanisms of allergic disease environmental and genetic determinants for the development of allergy. Clin Exp Allergy. 2015 May;45(5):844-58.

30 Mold JE, Michaëlsson J, Burt TD, Muench MO, Beckerman KP, Busch MP, et al. Maternal alloantigens promote the development of tolerogenic fetal regulatory $\mathrm{T}$ cells in utero. Science. 2008 Dec;322(5907):1562-5.

31 Underwood MA, Gilbert WM, Sherman MP. Amniotic fluid: not just fetal urine anymore. J Perinatol. 2005 May;25(5):341-8.

32 Medawar PB. Some Immunological and Endocrinological problems raised by the evolution of viviparity in vertebrates. Symp Soc Exp Biol. 1953;7:320-8.

33 McEwan M, Lins RJ, Munro SK, Vincent ZL, Ponnampalam AP, Mitchell MD. Cytokine regulation during the formation of the fetalmaternal interface: focus on cell-cell adhesion and remodelling of the extra-cellular matrix. Cytokine Growth Factor Rev. 2009 Jun;20(3): 241-9.

34 Ashkar AA, Di Santo JP, Croy BA. Interferon gamma contributes to initiation of uterine vascular modification, decidual integrity, and uterine natural killer cell maturation during normal murine pregnancy. J Exp Med. 2000 Jul;192(2):259-70.

35 Moreau P, Adrian-Cabestre F, Menier C, Guiard V, Gourand L, Dausset J, et al. IL-10 selectively induces HLA-G expression in human trophoblasts and monocytes. Int Immunol. 1999 May;11(5):803-11.

36 Saito S, Nakashima A, Shima T, Ito M. Th1/ Th2/Th17 and regulatory T-cell paradigm in pregnancy. Am J Reprod Immunol. 2010 Jun; 63(6):601-10.

37 Boldenow E, Jones S, Lieberman RW, Chames $\mathrm{MC}$, Aronoff DM, Xi C, et al. Antimicrobial peptide response to group B Streptococcus in human extraplacental membranes in culture. Placenta. 2013 Jun;34(6):480-5.

38 Spencer J, Dillon SB, Isaacson PG, MacDonald TT. T cell subclasses in fetal human ileum. Clin Exp Immunol. 1986 Sep;65(3):553-8.

39 Blom B, Res PC, Spits H. T cell precursors in man and mice. Crit Rev Immunol. 1998; 18(4):371-88

40 Michaëlsson J, Mold JE, McCune JM, Nixon DF. Regulation of $\mathrm{T}$ cell responses in the developing human fetus. J Immunol. 2006 May; 176(10):5741-8.

41 Tegethoff M, Greene N, Olsen J, Meyer AH, Meinlschmidt G. Maternal psychosocial adversity during pregnancy is associated with length of gestation and offspring size at birth: evidence from a population-based cohort study. Psychosom Med. 2010 May;72(4):41926.

42 Labouesse MA, Langhans W, Meyer U. Longterm pathological consequences of prenatal infection: beyond brain disorders. Am J Physiol Regul Integr Comp Physiol. 2015 Jul; 309(1):R1-12.
43 Avitsur R, Levy S, Goren N, Grinshpahet R. Early adversity, immunity and infectious disease. Stress. 2015;18(3):289-96.

44 Fortier ME, Luheshi GN, Boksa P. Effects of prenatal infection on prepulse inhibition in the rat depend on the nature of the infectious agent and the stage of pregnancy. Behav Brain Res. 2007 Aug;181(2):270-7.

45 Patterson PH. Maternal infection and immune involvement in autism. Trends $\mathrm{Mol}$ Med. 2011 Jul;17(7):389-94.

46 Vohr BR, Poggi Davis E, Wanke CA, Krebs NF. Neurodevelopment: The Impact of Nutrition and Inflammation during Preconception and Pregnancy in Low-Resource Settings. Pediatrics. 2017 Apr;139 Suppl 1:S38-49.

47 Hutton J. Does Rubella Cause Autism: A 2015 Reappraisal? Front Hum Neurosci. 2016 Feb; 10:25.

48 Slawinski BL, Talge N, Ingersoll B, Smith A, Glazier A, Kerver J, et al. Maternal cytomegalovirus sero-positivity and autism symptoms in children. Am J Reprod Immunol. 2018 May;79(5):e12840.

49 Maeyama K, Tomioka K, Nagase H, Yoshioka $\mathrm{M}$, Takagi Y, Kato T, et al. Congenital Cytomegalovirus Infection in Children with Autism Spectrum Disorder: Systematic Review and Meta-Analysis. J Autism Dev Disord. 2018 May;48(5):1483-91.

50 Gottfried C, Bambini-Junior V, Francis F, Riesgo R, Savino W. The Impact of Neuroimmune Alterations in Autism Spectrum Disorder. Front Psychiatry. 2015 Sep;6:121.

51 Rodríguez-Rojas R. Chapter 6. Neuroimages in autism. In: Robinson-Agramonte MA, editor. Translational Approaches to Autism Spectrum Disorder. Cham: Springer; 2015. p. 95-117.

52 Wegiel J, Kuchna I, Nowicki K, Imaki H, Wegiel J, Marchi E, et al. The neuropathology of autism: defects of neurogenesis and neuronal migration, and dysplastic changes. Acta Neuropathol. 2010 Jun;119(6):755-70.

53 Chen R, Jiao Y, Herskovits EH. Structural MRI in autism spectrum disorder. Pediatr Res. 2011 May;69(5 Pt 2):63R-8R.

54 Park MTM, Raznahan A, Shaw P, Goqtay N, Lerch JP, Chakravarty MM. Neuroanatomical phenotypes in mental illness: identifying convergent and divergent cortical phenotypes across autism, ADHD and schizophrenia. J Psychiatry Neurosci. 2018 Feb;43(2):170094.

55 Doherty GH. Developmental switch in the effects of TNFalpha on ventral midbrain dopaminergic neurons. Neurosci Res. 2007 Feb; 57(2):296-305.

56 Monje ML, Toda H, Palmer TD. Inflammatory blockade restores adult hippocampal neurogenesis. Science. 2003 Dec;302(5651): $1760-5$.

57 Morgan JT, Chana G, Pardo CA, Achim C, Semendeferi K, Buckwalter J, et al. Microglial activation and increased microglial density observed in the dorsolateral prefrontal cortex in autism. Biol Psychiatry. 2010 Aug;68(4): 368-76. 
58 Ashwood P, Krakowiak P, Hertz-Picciotto I, Hansen R, Pessah I, Van de Water J. Elevated plasma cytokines in autism spectrum disorders provide evidence of immune dysfunction and are associated with impaired behavioral outcome. Brain Behav Immun. 2011 Jan; 25(1):40-5.

59 Businaro R, Corsi M, Azzara G, Di Raimo T, Laviola G, Romano E, et al. Interleukin-18 modulation in autism spectrum disorders. J Neuroinflammation. 2016 Jan;13(1):2.

60 Kalkbrenner AE, Daniels JL, Chen JC, Poole C, Emch M, Morrissey J. Perinatal exposure to hazardous air pollutants and autism spectrum disorders at age 8. Epidemiology. 2010 Sep;21(5):631-41.

61 Li X, Chauhan A, Sheikh AM, Patil S, Chauhan V, Li XM, et al. Elevated immune response in the brain of autistic patients. J Neuroimmunol. 2009 Feb;207(1-2):111-6.

62 Wei H, Zou H, Sheikh AM, Malik M, Dobkin C, Brown WT, et al. IL-6 is increased in the cerebellum of autistic brain and alters neural cell adhesion, migration and synaptic formation. J Neuroinflammation. 2011 May;8(1): 52.
63 Wei H, Chadman KK, McCloskey DP, Sheikh AM, Malik M, Brown WT, et al. Brain IL-6 elevation causes neuronal circuitry imbalances and mediates autism-like behaviors. Biochim Biophys Acta. 2012 Jun;1822(6):831-42.

64 Wei H, Ma Y, Liu J, Ding C, Jin G, Wang Y, et al. Inhibition of IL-6 trans-signaling in the brain increases sociability in the BTBR mouse model of autism. Biochim Biophys Acta. 2016 Oct; 1862(10):1918-25.

65 Malkova NV, Yu CZ, Hsiao EY, Moore MJ, Patterson PH. Maternal immune activation yields offspring displaying mouse versions of the three core symptoms of autism. Brain Behav Immun. 2012 May;26(4):607-16.

66 Smith SE, Li J, Garbett K, Mirnics K, Patterson PH. Maternal immune activation alters fetal brain development through interleukin-6. J Neurosci. 2007 Oct;27(40):10695702.

67 Patel AS, Zalcman SS. Interleukin-2 treatment induces an acquired behavioral response pattern (repetitive stereotyped movements) mediated by dopamine D1 and D2 receptors. Int Neuropsychiatr Dis J. 2014;2(4): $175-85$.
68 Ahmad SF, Ansari MA, Nadeem A, Bakheet SA, Al-Ayadhi LY, Attia SM. Toll-like receptors, NF- $\kappa \mathrm{B}$, and IL-27 mediate adenosine $\mathrm{A} 2 \mathrm{~A}$ receptor signaling in BTBR $\mathrm{T}(+)$ Itpr3(tf)/J mice. Prog Neuropsychopharmacol Biol Psychiatry. 2017 Oct;79(Pt B):184-191.

69 Ansari MA, Nadeem A, Attia SM, Bakheet SA, Raish M, Ahmad SF. Adenosine A2A receptor modulates neuroimmune function through Th17/retinoid-related orphan receptor gammat $(\mathrm{ROR} \gamma \mathrm{t})$ signaling in a BTBR T+ Itpr3tf/J mouse model of autism. Cell Signal. 2017 Aug;36:14-24.

70 Ansari MA, Attia SM, Nadeem A, Bakheet SA, Raish M, Khan TH, et al. Activation of adenosine $\mathrm{A} 2 \mathrm{~A}$ receptor signaling regulates the expression of cytokines associated with immunologic dysfunction in BTBR T+ Itpr3tf/J mice. Mol Cell Neurosci. 2017 Jul;82:76-87.

71 Hamel R, Dejarnac O, Wichit S, Ekchariyawat P, Neyret A, Luplertlop N, et al. Biology of Zika Virus Infection in Human Skin Cells. J Virol. 2015 Sep;89(17):8880-96.

72 Olagnier D, Muscolini M, Coyne CB, Diamond MS, Hiscott J. Mechanisms of Zika Virus Infection and Neuropathogenesis. DNA Cell Biol. 2016 Aug;35(8):367-72. 